\title{
PENGARUH IKAN GABUS TERHADAP PENYEMBUHAN LUKA PERINEUM PADA IBU POST PARTUM DI PUSKESMAS SUNGAI PIRING TAHUN 2019
}

\author{
RikaAldesta $^{1}$, Rifa Rahmi ${ }^{2}$, Fajar Sari Tanberika ${ }^{2}$ \\ 1 Mahasiswa Kebidanan Program Sarjana Terapan STIKes Al Insyirah Pekanbaru \\ 2 Program Studi Kebidanan Program Sarjana Terapan STIKes Al-Insyirah Pekanbaru \\ Korespondensi: rikac09@gmail.com
}

\begin{abstract}
Handling of any cause of perineum rupture during childbirth should be done immediately with quality minimize the possibility of complications such as bleeding, infection, dyspareunia hematoma, and reduced libido that usually accompanies in the cause of perineum rupture. Snakehead Murrel is believed to accelerate wound healing because of its extract as a substitute for serum albumin which is usually used for surgical wound healing. The purpose of this study was to determine the effect of snakehead murrel on the healing of perineal wounds in postpartum mothers in the Public Health Center of Sungai Piring in 2019. This study used by quasi-experimental methods with a non-equivalent control group of 60 postpartum mothers who were divided into two groups namely the experimental group and the control group. The population was the first part of postpartum mothers with second-degree perineal injuries from January to June with a sample of 22 respondents. The sampling technique in this study was purposive sampling. Results: there was a healing of perineal wounds in all members of the experimental group and there was no healing in all control groups at the time of observation on 8th days. Conclusion: there was a significant effect of consuming Snakehead Murrel on the healing of perineal wounds in postpartum mothers.
\end{abstract}

Keywords: Snakehead Murrel, Perineum Wound Healing, Postpartum Mother

\begin{abstract}
ABSTRAK
Penanganan setiap kejadian robekan perineum saat mielahirkan harus segera dilakukan secara berkualitas, guna meminimalkan kemungkinan penyulit seperti pendarahan, infeksi, hematoma dispareunia dan libido berkurang yang biasa menyertai jika terjadi robekan perineum. Ikan gabus dipercaya dapat mempercepat penyembuhan luka karena ekstrak ikan gabus sebagai pengganti serum albumin yang biasanya digunakan untuk penyembuhan luka operasi. Tujuan penelitian untuk mengetahui Pengaruh Ikan Gabus Terhadap Penyembuhan Luka Perineum Pada Ibu Post Partum di Puskesmas Sungai PiringTahun 2019.Metode penelitian Quasy Experiment dengan Non equivalent control group. Rancangan ini melibatkan dua kelompok,
\end{abstract}


yaitu kelompok eksperimen dan kelompok kontrol. Populasi dalam penelitian ibu post partum hari pertama dengan luka perineum derajat II pada bulan Januari sampai Juni 2019 sebanyak 60 orang dengan sampel 22 responden. Teknik pengambilan sampel dalam penelitian ini adalah purposive sampling. Hasil penelitian menunjukan penyembuhan luka perineum pada seтиa anggota kelompok eksperimen dan tidak terdapat penyembuhan pada semua kelompok kontrol pada saat dilakukan observasi pada hari ke 8. Dapat disimpulkan terdapat pengaruh signifikan mengkonsumsi Ikan Gabus Terhadap Penyembuhan Luka Perineum Pada Ibu Post Partum.

Kata Kunci: Ikan Gabus, Penyembuhan Luka Perineum, Ibu Post Partum

\section{PENDAHULUAN}

Robekan jalan lahir merupakan salah satu kasus penyebab terjadinya infeksi pada masa nifas. Pada umumnya robekan jalan lahir terjadi pada persalinan dengan trauma. Pertolongan persalinan yang semakin manifulatif dan traumatik akan memudahkan robekan jalan lahir dan karena itu dihindarkan memimpin persalinan pada saat pembukaan serviks belum lengkap. Robekan jalan lahir biasanya akibat episiotomi, robekan spontan perineum, trauma forsep atau vakum ekstraksi, atau karena versi ekstraksi (Prawirohardjo, 2009).

Menurut world health organization (WHO) pada tahun 2014, angka kematian ibu di dunia yaitu 289.000 jiwa.Angka kematian ibu di negara-negara Asia Tenggara yaitu Indonesia sebesar 190/100.000 kelahiran hidup, Brunei Darussalam sebesar 27/100.000 kelahiran hidup dan Malaysia sebesar 29/100.000 kelahiran hidup (Manik, 2016). Perdarahan postpartum menjadi penyebab utama $40 \%$ kematian ibu di Indonesia. Salah satu hal yang memiliki andil besar dalam menyumbang angka kematian ibu yaitu pada proses persalinan dapat terjadi perdarahan. Perdarahan pada persalinan sering kali mengakibatkan perlukaan jalan lahir. Perlukaan jalan lahir dapat mengenai vulva, perineum, uterus, vagina, dan serviks. Salah satu jenis perlukaan jalan lahir adalah ruptur perineum (Aisya, dkk, 2018).

Data dari Dinas Kesehatan Provinsi Riau (2008) 35,63\% penyebab perdarahan postpartum adalah perlukaan jalan lahir, baik dengan tindakan episiotomi maupun robekan spontan (Dinas Kesehatan, 2008). Mengingat permasalahan yang dapat timbul sebagai akibat dari robekan 
perineum pada saat melahirkan, maka penanganan setiap kejadian robekan perineum harus segera dilakukan secara berkualitas, guna meminimalkan kemungkinan penyulit seperti pendarahan, infeksi, hematoma dispareunia dan libido berkurang yang biasa menyertai jika terjadi robekan perineum (Manuaba, 2007).

Pelayanan pasca persalinan harus terselenggara pada masa itu untuk memenuhi kebutuhan ibu dan bayiyang meliputi upaya pencegahan, deteksi dini dan pengobatan komplikasi dan penyakit yang mungkin terjadi, serta penyediaan pelayanan pemberian ASI, cara menjarangkan kehamilan, imunisasi, dan nutrisi bagi ibu (Prawirohardjo, 2009).

Nutrizi atau gizi adalah zat yang diperlukan oleh tubuh untuk keperluan metabolismenya. Kebutuhan gizi pada masa nifas akan meningkat 25\%, karena berguna untuk proses kesembuhan sehabis melahirkan. Menu makanan seimbang yang harus dikonsumsi adalah porsi cukup dan teratur serta kaya akan protein (Ambarwati, dkk, 2010).

Protein merupakan zat gizi yang sangat penting bagi tubuh karena selain sebagai sumber energi, protein berfungsi sebagai zat pengatur didalam tubuh. Selain zat pembangun, fungsi utamanya didalam tubuh adalah membentuk jaringan baru, disamping untuk memelihara jaringan yang telah ada. Fungsi protein sebagai zat pembangun tubuh adalah karena protein merupakan bahan pembentuk jaringan baru yang selalu terjadi didalam tubuh (Muchtadi,2010).

Menurut Ansar (2010) dalam penelitian Ulandari, dkk (2010) menjelaskan bahwa sejak dahulu ikan gabus dipercaya dapat mempercepat penyembuhan luka sehingga dianjurkan untuk dikonsumsi pasien pasca operasi dan ibu-ibu sehabis melahirkan. Hal ini dikarenakan ikan gabus mengandung protein yang tinggi.

Penelitian Eddy Suprayitno dari Fakultas Perikanan Universitas Brawijaya, Malang mengungkap pemanfaatan ekstrak ikan gabus sebagai pengganti serum albumin yang biasanya digunakan untuk penyembuhan luka operasi. Untuk pemanfaatan ikan gabus sebagai obat, ikan diambil ekstraknya dengan cara mengukusnya, lalu menampung airnya. Air ekstrak langsung diminumkan terhadap pasien yang baru selesai operasi. Dengan cara itu luka akan 
sembuh tiga hari lebih cepat dibanding bila diberi serum albumin (K. Kordi,2010).

Hasil penelitian menunjukkan bahwa ekstrak ikan gabus merupakan sumber mineral (seng, tembaga, dan besi) pendukung proses sintesis jaringan sehingga sangat berperan dalam proses penyembuhan luka. Mineral seng, tembaga, dan besi sangat diperlukan dalam berbagai proses metabolisme tubuh (Kusmini, dkk, 2018).

Menurut Yanti (2012) ikan gabus sangat kaya akan albumin. Ikan ini merupakan sumber albumin bagi penderita hipoalbumin (rendah albumin) dan luka, baik luka pasca operasi maupun luka bakar (Kusumaningrum, dkk, 2013).

Menurut Carvallo (1998), ikan gabus sendiri mempunyai senyawa yang penting bagi tubuh, seperti protein dan beberapa mineral. Kadar protein ikan gabus mencapai 25,5\% . Dibandingkan protein ikan lainnya, albumin ikan gabus cukup tinggi mencapai $6,22 \%$ dan daging ikan gabus mengandung mineral seng dengan kadar 1,74 mg/100 gram (Fitriyani, dkk, 2013).

Berdasarkan studi pendahuluan dan survei yang dilakukan pada tanggal 10 - 27 Juni 2019 di Puskesmas Sungai Piring dengan cara mendatangi dan mewawancarai ibu post partum, dari 10 ibu post partum 7 diantaranya tidak mengetahui bahwa ikan gabus merupakan sumber mineral, protein, dan albumin yang tinggi, yang dapat mempercepat proses penyembuhan luka perineum. Selain itu ibu post partum tidak mengetahui cara pengolahan ikan gabus agar tidak berbau amis pada saat dikonsumsi.

Berdasarkan latar belakang diatas peneliti tertarik untuk mengajukan penelitian dengan judul “ Pengaruh Ikan Gabus Terhadap Penyembuhan Luka Perineum Pada Ibu Post Partum di Puskesmas Sungai Piring Tahun 2019“. Tujuan penelitian untuk mengetahui Pengaruh Ikan Gabus Terhadap Penyembuhan Luka Perineum Pada Ibu Post Partum di Puskesmas Sungai Piring Tahun 2019.

\section{METODE}

Penelitian ini menggunakan metode penelitian Quasy Experiment dengan Non equivalent control group. Rancangan ini melibatkan dua kelompok, yaitu kelompok eksperimen dan kelompok kontrol, dilakukan di Puskesmas Sungai Piring yang di mulai 
pada bulan November 2019 sampai bulan Januari Tahun 2020. Populasi dalam penelitian ini adalah seluruh subjek yang memenuhi kriteria yang telah ditetapkan yaitu ibu post partum hari pertama dengan luka perineum derajat II pada bulan Januari sampai Juni 2019 sebanyak 60 orang di Puskesmas Sungai Piring dengan jumlah sampel 22 responden (11 orang untuk kelompok intervensi dan 11 orang untuk kelompok kontrol). Teknik pengambilan sampel adalah purposive sampling. Analisa univariat digunakan untuk mendeskripsikan variabel penelitian guna memperoleh gambaran atau karakteristik sebelum dilakukan analisa bivariat. Hasil dari penelitian di tampilkan dalam bentuk distribusi frekuensi. Analisis bivariat dilakukan untuk menganalisa pengaruh antara pemberian ikan gabus terhadap penyembuhan luka perineum pada ibu post partum.

\section{HASIL DAN PEMBAHASAN}

Hasil penelitian menunjukkan bahwa Mayoritas umur kelompok ekperimen berada pada 19-23 tahun (45,5\%), umumnya berpendidikan tinggi (SMA 54,5\% dan S1 45,5\%), mayoritas $(45,5 \%)$ bekerja sebagai ibu rumah tangga, semua kelompok eksperimen diberikan ikan gabus dan semua (100\%) terdapat penyembuhan luka perineum pada hari ke 8 saat diobservasi. Mayoritas umur kelompok kontrol berada pada 24-28 tahun (45,5\%), umumnya berpendidikan rendah ( SD $54,5 \%$ dan SMP 45,5\%) semuanya (100\%) hanya bekerja sebagai ibu rumah tangga. Semua kelompok kontrol yang tidak diberikan ikan gabus tidak ada penyembuhan luka perineum pada hari ke 8 saat diobservasi.

Tabel 1: Pengaruh Ikan Gabus Terhadap Penyembuhan Luka Perineum Pada Ibu Post Partum di Puskesmas Sungai Piring Tahun 2019

\begin{tabular}{|c|c|c|c|c|c|c|c|}
\hline \multirow{3}{*}{$\begin{array}{c}\text { Penyembuhan } \\
\text { Luka } \\
\text { Perineum }\end{array}$} & \multicolumn{4}{|c|}{ Pemberian Ikan Gabus } & & & \multirow{2}{*}{$\begin{array}{c}P \\
\text { value } \\
\end{array}$} \\
\hline & \multicolumn{2}{|c|}{ Kontrol } & \multicolumn{2}{|c|}{ Eksperimen } & \multicolumn{2}{|c|}{ Total } & \\
\hline & $\mathrm{N}$ & $\%$ & $\mathrm{~N}$ & $\%$ & $\mathrm{~N}$ & $\%$ & \\
\hline Tidak & 11 & 100,0 & & & 11 & 50,0 & 0,000 \\
\hline Ya & & & 11 & 100,0 & 11 & 50,0 & \\
\hline Total & 11 & 100,0 & 11 & $\overline{100,0}$ & 22 & 100 & \\
\hline
\end{tabular}


Berdasarkan pada tabel 1 di atas diketahui kelompok kontrol yang tidak diberikan ikan gabus, saat dilakukan observasi pada hari ke 8 didapati semua $(100 \%)$ belum terjadi penyembuhan pada luka perineum, sedangkan pada kelompok eksperimen yang diberikan ikan gabus sebanyak 700 gr setiap hari selama 7 hari, didapati $100 \%$ penyembuhan terjadi pada luka perineum (sembuh). Hasil uji Chi Square diperoleh $\mathrm{P}$ value $0,000<\alpha$, artinya terdapat pengaruh yang signifikan pemberian ikan gabus terhadap penyembuhan luka perineum.

Berdasarkan hasil penelitian diketahui bahwa kelompok eksperimen yang mengkonsumsi ikan gabus 700 gram perhari berturut turut selama 7 hari saat dilakukan observasi pada hari ke 8 semua $(100 \%)$ luka perineum sembuh. Sedangkan pada kelompok kontrol yang tidak diberikan ikan gabus tidak ada penyembuhan luka perineum pada hari ke-8 saat diobservasi. Terdapat pengaruh yang signifikan pemberian ikan gabus terhadap penyembuhan luka perineum.

Penelitian ini sejalan dengan Setyarini, dkk (2012) dengan mengkonsumsi protein ikan gabus dalam bentuk gel sebanyak 2 x 70 gram perhari selama 7 hari luka perineum sudah menutup dengan baik pada hari ke 8 dan tidak ada tanda-tanda infeksi.

Penelitian ini juga sejalan dengan riset yang dilakukan oleh Prof. Dr. Eddy Suprayitno, Ms. Dosen di Fakultas Perikanan Universitas Brawijaya yang mengungkap kandungan albumin ikan gabus yang berkhasiat mengatasi luka.

Menurut Waryana (2010) dalam penelitian Karina, dkk (2016) Nutrisi yang dibutuhkan untuk penyembuhan luka yaitu mengkonsumsi makanan yang serat akan protein. Protein didapatkan pada makanan, daging dan ikan. Semua jenis ikan adalah sumber protein yang sangat baik. Ikan gabus diketahui sebagai ikan dengan kandungan gizi dan protein yang lebih banyak dari ikan jenis lainnya. Keunggulan ikan gabus mempunyai protein yang tinggi, kadar protein per 100 gram ikan gabus setara dengan ikan bandeng.

Nutrizi atau gizi adalah zat yang diperlukan oleh tubuh untuk keperluan metabolismenya. Kebutuhan gizi pada masa nifas akan meningkat $25 \%$, karena berguna untuk proses kesembuhan sehabis melahirkan. Menu makanan seimbang yang harus dikonsumsi adalah 
porsi cukup dan teratur serta kaya akan protein (Ambarwati, dkk, 2010).

Pemberian ekstrak ikan gabus pada kelompok eksperimen dimaksudkan untuk mempercepat penyembuhan luka perineum. Sebab ikan gabus merupakan salah satu jenis ikan yang kandungan utamanya adalah protein atau albuminnya yang cukup tinggi. Karena kandungan protein dan albuminnya yang tinggi, serta asam amino yang lengkap, ikan gabus cocok dikonsumsi pasien luka bakar, pasien pasca operasi atau orang yang dalam masa penyembuuhan, orang tua yang fungsi organnya mulai menurun maupun anak-anak yang mengalami malnutrisi (K. Kordi, 2010).

Peran utama albumin di dalam tubuh sangat penting, yaitu membantu pembentukkan jaringan sel baru. Tanpa albumin, sel-sel didalam tubuh akan sulit beregenerasi sehingga cepat mati dan tidak berkembang. Albumin juga berperan penting dalam proses penyembuhan luka. Di dalam ilmu kedokteran, albumin biasa dimanfaatkan untuk mempercepat pemulihan jaringan sel tubuh, misalnya karena operasi atau pembedahan. Itulah sebabnya pasien pasca operasi sangat dianjurkan mengonsumsi ikan gabus dengan harapan dapat membantu proses penyembuhan di dalam tubuh (Kusmini, 2018).

Proses penyembuhan luka pada umumnya dibagi atas beberapa fase yang masing- masing saling berkaitan yaitu fase inflamasi, proliferasi, dan maturasi. Kolagen adalah komponen kunci pada fase dari penyembuhan luka. Segera setelah terjadi trauma jaringan, paparan kolagen fibriler ke darah akan menyebabkan agregasi dan aktivasi trombosit dan melepaskan faktor- faktor kemotaksis yang memulai proses penyembuhan luka. Fragmen fragmen kolagen melepaskan kolagenase leukositik untuk menarik fibroblas ke daerah trauma jaringan. Selanjutnya kolagen menjadi pondasi untuk matriks ekstraseluler yang baru (Pramoto, dkk, 2016).

Proses penyembuhan luka akan dimulai segera setelah terjadinya kerusakan, akan tetapi mekanisme dan kecepatan yang pada akhirnya akan memperbaiki jaringan yang rusak bergantung pada tipe luka. Proses penyembuhan luka pada dasarnya merupakan suatu proses seluler yang kompleks dan berfokus untuk mengembalikan keutuhan jaringan yang rusak. Kejadian ini melibatkan beberapa 
fenomena seluler seperti migrasi, proliferasi, adhesi, diferensiasi, dan sebagainya. Untuk menghasilkan penyembuhan luka yang efektif, tubuh harus mensuplai material dan nutrisi (Sugiaman, 2011).

Menurut hasil penelitian dengan mengkonsumsi ikan gabus secara rutin dengan jumlah yang tepat dapat mempercepat penyembuhan luka perineum, yaitu luka sudah dinyatakan sembuh pada hari ke 8. Hal ini dikarenakan ikan gabus memiliki kandungan albumin yang tinggi. Albumin ini di dalam tubuh sangat penting, karena dapat mempercepat pembentukkan jaringan sel baru. Tanpa albumin, sel-sel didalam tubuh akan sulit beregenerasi sehingga cepat mati dan tidak berkembang. Albumin juga berperan penting dalam proses penyembuhan luka. Karena itu, disarakan kepada ibu yang baru melahirkan untuk mengkonsumsi ikan gabus secara teratur setiap hari agar proses penyembuhan luka perineum dapat berlangsung dengan cepat. Sedangkan pada ibu yang tidak mengkonsumsi ikan gabus, pada saat dilakukan observasi pada hari ke 8 , luka perineum masih dinyatakan belum sembuh, hal ini disebabkan oleh budaya dan kepercayaan masyarakat yang tidak memperbolehkan ibu post partum untuk mengkonsumsi ikan, telur, dan daging selama masa nifas sehingga ibu post partum tidak mendapatkan asupan protein untuk penyembuhan luka perineum.

\section{SIMPULAN}

Berdasarkan hasil penelitian tentang Pengaruh Ikan Gabus Terhadap Penyembuhan Luka Perineum Pada Ibu Post Partum Di Puskesmas Sungai Piring dapat disimpulkan sebagai berikut:

1. Dengan mengkonsumsi ikan gabus 700 gram perhari selama 7 hari berturut-turut pada kelompok eksperimen, didapati 100\% ibu post partum mengalami penyembuhan luka perineum pada saat diobservasi pada hari ke 8 .

2. Untuk kelompok kontrol yang tidak mengkonsumsi ikan gabus, pada saat diobservasi pada hari ke 8 didapati $100 \%$ ibu post partum belum mengalami penyembuhan luka perineum. Dinyatakan belum sembuh karena masih ada luka perineum yang merah, basah, bengkak, dan belum terdapat jaringan parut. 
3. Terdapat pengaruh yang DiaksesTanggal 29 Agustus signifikan dimana hasil uji $C h i$ 2019 Square diperoleh P value 0,000 < $\alpha$, artinya terdapat pengaruh ikan gabus terhadap penyembuhan luka perineum.

\section{DAFTAR PUSTAKA}

Aisya, Masmuni Wahda, dkk. 2018. Hubungan Teknik Mengedan dengan Kejadian Ruptur Perineum pada Ibu Bersalim di Puskesmas Tibawa Kabupaten Gorontalo. Fakultas Ilmu Kesehatan Universitas Muhammadiyah Gorontalo. DiaksesTanggal 29 Agustus 2019: SKRIPSI

Ambarwati, Eny Ratna, dkk. 2010. Asuhan Kebidanan Nifas. Jogjakarta: Mitra Cendikia Press Dinas Kesehatan Provinsi Riau. 2016. Profil Kesehatan Provinsi Riau 2016. Pekanbaru

Fitriyani, Evi dan Ika Meidy Deviarni. 2013. Pemanfaatan Ekstrak Albumin Ikan Gabus (ChannaStriata) Sebagai Bahan Dasar Cream Penyembuh Luka, Volume IX, Nomor 3, November 2013, Politeknik Negeri Pontianak 78124, 
Mulyorejo - Surabaya, Diakses

Tanggal 29 Agustus 2019

Manuaba, I. B. G. 2007. Pengantar

Kuliah Obstetri. Jakarta: EGC

Muchtadi,Deddy. 2010. Teknik

Evaluasi Nilai Gizi Protein.

Bandung: Alfabeta

Prawirohardjo, Sarwono. 2009. Ilmu

Kebidanan

Sarwono

Prawirohardjo. Jakarta: Bina

Pustaka Sarwono Prawirohardjo

Setyarini, Didien Eka, dkk. 2012.

Gambaran Penyembuhan Luka

Perineum

dengan

Mengkonsumsi Ekstrak Ikan

Gabus (Channa Striata). Jurnal

Kesehatan, Volume II, No. 2,
November 2013: 184-189,

Poltekkes Kemenkes Malang,

Diakses Tanggal 29 Agustus

2019

Sugiaman, Vinna K. 2011. Peningkatan Penyembuhan Luka di Mukosa Oral Melalui Pemberian Aloe Vera (Linn.) Secara Topikal. JKM. Vol.11 No.1 Juli 2011:70-79, Program Studi Kedokteran Gigi, Universitas Kristen Maranatha, Diakses Tanggal 2 Maret 2020 